\title{
LEE WAY SPACE MANDIBULA PADA SISWA SUKU MINANG DI SEKOLAH DASAR LUBUK SIKAPING, SUMATERA BARAT
}

\author{
Ayu Shafira1, Hafni Bachtiar², Didin K ${ }^{1}$ \\ ${ }^{1}$ Fakultas Kedokteran Gigi Universitas Andalas \\ ${ }^{2}$ Fakultas Kedokteran Universitas Andalas
}

\begin{abstract}
The prediction of permanent size of theet which haven't errupted to determine the value of place needed, availability of space and predict the storage of space. Is one of important aspect in diagnosis and treatment planning on the period of mixed dentition. Prediction method that used commonly is Moyers method which the data is taken from Kaukasoid ras. The objective of the research is to see the difference of leeway space of mandibula on Minang man and woman students of elemantary school Lubuk Sikaping. The method of this research is cross sectional comprative study. 56 samples of mandibula study are taken from the student of SDN 06 Pauh, SDN 09 Pauh, and SDN 10 Pauh Lubuk Sikaping at the age of 8 to 10 years and they are Minangnese. The results are analyzed statistically by $t$-test on significant degree 95\%. This research indicates that the large average of man mandibula leeway space on the left $(1,76 \mathrm{~mm})$ and on the right $(1,85 \mathrm{~mm})$. And the average of leeway space of woman mandibula leeway space on the left $(2,03 \mathrm{~mm})$ and on the right $(2,16 \mathrm{~mm})$. The analyze t-test result on the significant degree $95 \%$ show there is no significant difference $(p>0,05)$ between man and woman students. Therefore, it can be concluded that the large average of leeway space of man and woman mandibula in Minang students of elementary school Lubuk Sikaping showed no significant difference in size.
\end{abstract}

Keywords: leeway space, moyers method, period of mixed dentition

Affiliasi penulis: ${ }^{1}$ Fakultas Kedokteran Gigi Universitas Andalas Korespondensi: didin k, email: drg.didin@yahoo.com

\section{PENDAHULUAN}

Fase gigi bercampur adalah suatu fase ditemukan adanya gigi desidui dan gigi permanen bersamaan di dalam rongga mulut. Fase gigi bercampur dimulai dari usia 6 tahun ketika molar pertama erupsi dan berakhir sekitar usia 12 tahun. Kebanyakan kasus maloklusi terbentuk selama fase ini. ${ }^{1}$ Pada pergantian kaninus dan molar desidui oleh kaninus permanen dan premolar terdapat kelebihan ruang akibat adanya perbedaan lebar mesiodistal gigi desidui dengan gigi penggantinya, selisih ruang ini disebut Nance dengan leeway space. ${ }^{2}$ Nance menyatakan bahwa leeway space pada rahang atas rata-rata 0,9 milimeter pada tiap sisi, sedangkan untuk mandibula rata-rata 1,7 milimeter. Hal ini telah dibuktikan oleh G.V. Black dengan cara menghitung lebar mesio distal dari gigi desidui (kaninus, molar pertama, dan molar kedua) dan lebar mesio distal dari gigi permanen (kaninus, premolar pertama, dan premolar kedua). ${ }^{2}$

Terdapat beberapa metode prediksi ukuran mesiodistal gigi kaninus dan premolar yang belum erupsi dalam bidang ortodonsia. Salah satu metode yang sering digunakan adalah metode 
Moyers. Metode Moyers merupakan metode prediksi yang sering digunakan, karena kesalahan sedikit dan ralat kecil sehingga diketahui dengan tepat, dapat dikerjakan ahli atau bukan ahli, tidak butuh banyak waktu, tidak perlu alat khusus, dapat dikerjakan dalam mulut atau model, baik pada rahang atas atau rahang bawah. Metode prediksi Moyers datanya diperoleh dari ras Kaukasoid sehingga akurasi dari metode ini dipertanyakan ketika diaplikasikan untuk ras dan suku yang berbeda. Moyers membuat tabel probabilitas untuk mendapatkan ruang yang diperlukan dalam menyelaraskan gigi kaninus, premolar pertama dan premolar kedua permanen atas dan bawah, dengan menggunakan jumlah dari empat gigi seri permanen mandibula. ${ }^{3}$

Analisis ruang ini memiliki dua komponen, yaitu available space dan required space $)^{4}{ }^{4}$ Available space adalah ruangan yang tersedia dari distal gigi insisivus lateral permanen ke mesial gigi molar pertama permamen untuk erupsi gigi kaninus dan premolar permanen. Required space adalah ruang yang dibutuhkan untuk erupsi gigi kaninus dan premolar permanen. Perbedaan antara besar available space dan required space ini menyebabkan terjadi maloklusi. Suatu penelitian mengenai besar leeway space dilakukan oleh Hanihara (1976) di Jepang pada kelompok etnik Jepang. Dari penelitian tersebut diketahui bahwa leeway space rahang atas pada laki-laki sebesar 1,0 mm dan pada perempuan sebesar 0,9 $\mathrm{mm}$, serta besar leeway space mandibula sebesar 2,9 $\mathrm{mm}$ pada laki-laki dan perempuan. ${ }^{5}$ Selain itu Brown et al(1980) melakukan penelitian mengenai leeway space pada suku Aborigin, Australia. Suku Aborigin Australia termasuk kedalam ras Negroid. Dari penelitian tersebut diketahui bahwa leeway space rahang atas pada laki-laki sebesar 1,4 mm dan pada perempuan sebesar $1,3 \mathrm{~mm}$, serta untuk leeway space pada mandibula pada laki-laki sebesar 2,8 $\mathrm{mm}$ dan pada perempuan sebesar $3,3 \mathrm{~mm} .^{5}$

Penelitian yang sama juga dilakukan di Indonesia yaitu pada suku Banjar. Dari penelitian tersebut disimpulkan bahwa rerata leeway space rahang atas pada suku Banjar lebih kecil dari leeway space menurut Proffit, yaitu sebesar $0,37 \mathrm{~mm}$ di setiap region. ${ }^{6}$ Penelitian mengenai leeway space juga dilakukan pada suku Bugis, yang mana hasil penelitian tersebut menyatakan bahwa tidak ada perbedaan yang signifikan antara besar leeway space pada laki-laki dan perempuan baik rahang atas maupun mandibula. ${ }^{3}$ Selain pada suku Banjar dan Bugis penelitian mengenai besar leeway space juga dilakukan pada suku Batak. Hasil 
penelitian oleh Maria Ulfa tersebut menyimpulkan bahwa rerata besar leeway space pada rahang atas untuk pasien laki-laki adalah 2,39 $\mathrm{mm}$ dan untuk perempuan adalah 2,66 mm. Pada mandibula rerata besar leeway space pasien laki-laki adalah 2,79 $\mathrm{mm}$ dan perempuan $2,68 \mathrm{~mm}^{7}$

Mengingat Indonesia memiliki keragaman suku bangsa, penulis tertarik melakukan penelitian yang sama pada suku Minang. Suku Minang merupakan suku asli Sumatera Barat dan termasuk dalam ras Deurto-Melayu yang merupakan sub ras dari ras Mongoloid. Selain itu suku Minang merupakan salah satu suku di Indonesia yang menganut garis keturanan matrilineal, yaitu garis keturunan menurut garis keturunan ibu. Lubuk Sikaping merupakan satu dari 12 kecamatan yang ada di kabupaten Pasaman. Berdasarkan hasil Sensus Penduduk tahun 2010, penduduk kabupaten Pasaman berjumlah 253.299 jiwa. Di antara 12 kecamatan di kabupaten Pasaman penduduk terbanyak berada di Lubuk Sikaping dengan jumlah penduduk 43.746 jiwa sekaligus menjadi ibukota kabupaten Pasaman, maupun pusat pemerintahannya. Mayoritas masyarakat Lubuk Sikaping adalah suku Minang, selain itu di Lubuk Sikaping juga terdapat beberapa suku pendatang seperti suku Batak dan Jawa.

\section{METODE}

Metode yang digunakan dalam penelitian ini adalah analitik obsevasional dengan pendekatan komparatif cross-sectional. Besar sampel dihitung dengan rumus sampel tidak berpasangan dan didapatkan banyak sampel untuk masing-masing kelompok sampel adalah 25. Untuk mengantisipasi terjadi kesalahan digunakan rumus koreksi dan didapatkan total sampel untuk masingmasing kelompok sampel adalah 28 . Alat yang digunakan pada penelitian adalah sliding kaliper, sendok cetak, rubber bowl, dan spatula. Bahan yang digunakan adalah bahan cetak irreversible (alginat) dan gips tipe III. Prosedur penelitian dimulai dengan melakukan survei awal dan pemeriksaan keadaan gigi untuk menentukan sampell yang masuk pada kriteria inklusi dan ekslusi. Kemudian dilakukan pencetakan mandibula sampel untuk mendapatkan model studi mandibula. Setelah itu dilakukan pengukuran lebar mesiodistal 4 gigi insisivus rahang bawah, available space, dan required space menggunakan sliding kaliper. Hitung selisih availabe space dan required space untuk mendapatkan besar leeway space. Data yang diperoleh dianalisis menggunakan uji Independent T-Test jika sebaran data normal dan uji Mann-Withney. 
HASIL DAN PEMBAHASAN

Tabel 1. Rata-Rata Besar Leeway Space Mandibula Pada Siswa Sekolah Dasar Suku Minang Lubuk Sikaping Berdasarkan Jenis Kelamin Glukonat $0,2 \%$

\begin{tabular}{lccc}
\hline \multirow{2}{*}{ Pengukuran } & \multicolumn{2}{c}{$\mathbf{x} \pm \mathbf{S D}(\mathbf{m m})$} & \\
\cline { 2 - 3 } & $\begin{array}{c}\text { Laki-Laki } \\
(\mathbf{n = 2 8})\end{array}$ & $\begin{array}{c}\text { Perempuan } \\
(\mathbf{n = 2 8})\end{array}$ & \\
\hline $\begin{array}{l}\text { Leeway } \\
\text { Space sisi kiri }\end{array}$ & $1,76 \pm 0,79$ & $2,03 \pm 0,72$ & 0,603 \\
$\begin{array}{l}\text { Leeway } \\
\begin{array}{l}\text { Space sisi } \\
\text { kanan }\end{array}\end{array}$ & $1,85 \pm 0,68$ & $2,16 \pm 0,98$ & 0,506 \\
\hline
\end{tabular}

Tabel di atas menunjukkan ratarata besar leeway spacemandibula untuk laki-laki sebesar 1,76 milimeter untuk sisi kiri dengan simpangan baku sebesar 0,79 milimeter dan sebesar 1,85 milimeter untuk sisi kanan dengan simpangan baku 0,68 milimeter. Pada responden perempuan rata-rata besar leeway space mandibula adalah 2,03 milimeter untuk sisi kiri dengan simpangan baku 0,72 milimeter dan untuk sisi kanan sebesar 2,16 milimeter dengan simpangan baku 0,9 milimeter. Hasil analisis independent sample t-test dengan derajat kemaknaan 95\% menunnjukkan nilai $p>0,05$ dapat disimpulkan bahwa tidak ada perbedaan yang signifikan antara besar leeway space mandibula laki-laki dan perempuan baik pada sisi kiri maupun pada sisi kanan.

Lebar mesiodistal gigi dan panjang lengkung rahang dipengaruhi oleh beberapa faktor, diantaranya faktor ras dan jenis kelamin. Dalam penelitian ini, peneliti membahas tentang leeway space pada siswa suku Minang (ras Deuteromelayu) sekolah dasar Lubuk Sikaping serta membedakannya berdasarkan jenis kelamin menggunakan metode analisis ruang Moyers. Sebanyak 56 model studi mandibula diperoleh dari siswa SDN 06 Pauh, SDN 09 Pauh, dan SDN 10 Pauh yang bersuku Minang kemudian dilakukan pengukuran dengan tabel probabilitas Moyers level 75\%.

Leeway space adalah ruangan yang terbentuk karena adanya perbedaan lebar mesiodistal gigi pada pergantian gigi kaninus, molar pertama dan molar kedua desidui oleh kaninus, premolar pertama dan premolar kedua permanen. Leeway space berperan penting dalam periode gigi bercampur karena pada periode ini leeway space dapat dimanfaatkan untuk mengatasi kekurangan ruang yang terjadi pada periode tumbuh kembang. ${ }^{21,39}$ Hasil penelitian menunjukkan rata-rata besar leeway space mandibula sedikit lebih besar jika dibandingkan dengan besar leeway space rahang atas menurut Moyers. Hal ini disebabkan karena gigi molar desidui mandibula lebih besar dibandingkan dengan gigi molar desidui rahang atas. ${ }^{14}$ Selain itu ukuran gigi premolar mandibula memiliki ukuran yang lebih kecil dari gigi molar desidui sehingga akan memberikan kelebihan ruangan yang lebih besar pada 
mandibula. Gigi molar kedua desidui ini memiliki selisih lebar hingga $2 \mathrm{~mm}$ lebih besar dibandingkan dengan gigi premolar kedua permanen. Gigi molar mandibula biasanya bergerak lebih ke mesial dibandingkan dengan gigi molar rahang atas. Selama oklusi normal ini berlangsung, sekitar $2 \mathrm{~mm}$ dari leeway space akan digunakan untuk pergerakan ke anterior oleh gigi molar permanen. ${ }^{15,20}$

Hasil uji statistik menyatakan bahwa tidak ada perbedaan yang signifikan antara besar leeway space laki-laki dan perempuan ( $p>0,05)$. Besar leeway space dipengaruhi oleh beberapa faktor salah satunya adalah jenis kelamin. Sebuah penelitian oleh Stroud et al pada tahun 1994 dapat disimpulkan bahwa ukuran gigi sangat dipengaruhi oleh jenis kelamin, yang mana ukuran gigi laki-laki lebih besar dibandingkan dengan perempuan. ${ }^{34}$ Pada tahun 1971 Alvesalo menyatakan bahwa ukuran gigi dipengaruhi oleh jenis kelamin. ${ }^{35}$ Sebaliknya, hasil penelitian ini tidak ditemukan bahwa ada perbedaan yang signifikan antara hasil pengukuran pada laki-laki dan perempuan. Hal ini cenderung membenarkan penelitian yang dilakukan oleh Rizki AR (2014) mengenai leeway space yang dilakukan pada suku Bugis (ras Deutro-Melayu), hasil penelitian tersebut menyatakan bahwa tidak ada perbedaan yang signifikan antara besar leeway space pada laki-laki dan perempuan baik rahang atas maupun mandibula. ${ }^{3}$ Selain itu penelitian yang sama juga dilakukan pada suku Batak (ras Proto-Melayu). Penelitian yang dilakukan oleh Maria Ulfa (2009) tersebut menyimpulkan bahwa rerata besar leeway space pada rahang atas untuk pasien laki-laki adalah 2,39 mm dan untuk perempuan adalah 2,66 mm. Pada mandibula rerata besar leeway space untuk pasien laki-laki adalah 2,79 $\mathrm{mm}$ dan untuk perempuan 2,68 mm, artinya tidak terdapat perbedaan yang signifikan antara besar leeway space pada pasien laki-laki dan perempuan. $^{7}$

Faktor lain yang dapat mempengaruhi ukuran gigi geligi adalah faktor genetik. Penelitian yang dilakukan Lundstrom membandingkan antara 97 pasangan kembar monozigot dan dizigot ditemukan bahwa terdapat hubungan faktor genetik yang kuat pada kembar monozigot terhadap ukuran gigi dan morfologi gigi. Penelitian tersebut berhasil membuktikan bahwa terdapat kesamaan ukuran dan bentuk gigi pada kembar zigomatik. ${ }^{32}$ Penelitian sebelumnya menyatakan pengaruh faktor genetik sangat kuat yaitu dengan estimasi gambaran morfologis mahkota sebesar $90 \% .^{36}$ Alvaleso pada tahun 1971 menyatakan bahwa ukuran gigi 
dipengaruhi oleh jenis kelamin, dalam hal ini yang mempengaruhi perbedaan tersebut adalah faktor genetik kromosom $\mathrm{X}$ dan $\mathrm{Y}^{35}$ Penelitian lain oleh $\mathrm{P}$ J Dempsey dan G C Townsend pada tahun 2001 menyimpulkan bahwa faktor genetik sangat berpengaruh terhadap variasi ukuran gigi. ${ }^{37}$

\section{SIMPULAN}

Tidak ada perbedaan yang signifikan $(\mathrm{p}>0,05)$ antara besar leeway space mandibula laki-laki dan perempuan baik pada sisi kiri maupun pada sisi kanan dan rerata besar leeway space mandibula siswa suku Minang sekolah dasar adalah sebesar 1,89 milimeter pada sisi kiri dan 2,01 milimeter pada sisi kanan.

\section{KEPUSTAKAAN}

1. C.Scheid Rickne dan Gabriela Weiss. Woelfel's Dental Anatomy Edition, Publisher: ZIFATAMA; 2016.

2. Heryumani. Metode perhitungan dalam perawatan ortodontik. Bagian ortodonsia FKG UGM; 2008.

3. Awaliyah Rizkiani Ramli. Validitas Indeks Moyers Di SDN 28 Tumampua Pangkajene [Makassar : Universitas Hassanudin; 2014.

4. Boboc Alin dan Jos Dibbet. Prediction of the mesiodistal width of unerupted permanent canines and premolars: A statistical approach.
Marburg, Germany, and Sibiu, Romania; 2010.

5. Shaw, WC. Orthodontics and Occlusal Management.Oxford, UK: Butterworth-Heinemann Ltd; 1993. p. 55 .

6. Meidy Gusti L, Fajar Kusuma D.K., Irnamanda D.H. Perbandingan rerata besaran leeway space suku banjar dengan rerata leeway space menurut Proffit:Odonto Dental Journal; 2016; Volume 3. Nomer 1.

7. Ulfa Maria. Prediksi Leeway Space Menggunakan Tabel Moyers Pada Pasien Yang Dirawat Di Klinik Ortodonsia FKG USU. Departemen Ortodonsia Fakultas Kedokteran Gigi Universitas Sumatera Utara [Medan; FKG USU; 2009.

8. Mathewson RJ, Primosch RE. Fundamentals of Pediatric Dentistry. 3ed. Quintessence Books. p. 31.

9. Bhalajhi SI. Orthodontics the art and science. $1^{\text {st }}$ Ed. New Delhi : Arya (medi) publishing house; 1977. p.56-60.

10. Duterloo, H.S. An Atlas of Dentition in Chilhood. Wolfe Publishing Ltd. England; . 1991. p. 69-85

11. Basavaraj, SP. Orthodontics: Principles and Practice.New Delhi, India: JP Medical Ltd; 2011.pp. 657. 
12. Singh G. Textbook of orthodontics. 2nded. New Delhi: Jaypee Brother Medical Publisher Ltd; . 2007.p. 3748.

13. Rao, A. Principles and Practice of Pedodontics. $2^{\text {nd }}$ edition. New Delhi, India: Jaypee Brothers Publisher; 2008. p. 70-6.

14. Phulari BS.Orthodontics principles

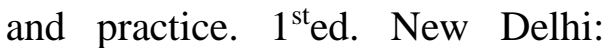
Jaypee brothers medical publishers; 2011; 74-5.

15. English JD, Peltomaki T, PhamLitschel K. Orthodontic review. St. Louis: Mosby year book; 2010; 1321.

16. Dasgupta B, Zahir S. Comparison of two non-radiographic techniques of mixed dentition space analysis and evaluation of their reliability for Bengali population. Contemp Clin Dentistry; 2012; 3(2); p.146-150.

17. Vyas MB, Hantodkar N. Resolving mandibular arch discrepancy through utilization of Leeway space: Contemporary Clinical Dentistry; 2011; 2(2) : 115-8.

18. Proffit WR, Field Jr HW, Sorver DM. Contemporary orthodontics [ebook].5th.ed.St.Louis(Messouri):

Mosby; 2014.

19. Nafisah R, Syafei A, Goerharto S. Besar leeway space pada pasien ortodonti di RSGM FKG UNAIR. Orthodontic DentJ; 2010; 1(2):6-10.
20. Hille HM. The mean leeway space in a popuation of orthodontic patients in Zurich [Zurich: Universitat Zurich; 2010; p.1-23.

21. Laviana A. Analisis model studi sumber informasi penting bagi diagnosis ortodonti. Bagian Ortodonsi Fakultas Kedokteran Gigi Universitas Padjajaran. Bandung; 2011.

22. AI-Khandra Basil Hussain , BDS, MS. Prediction of the size of unerupted canines and premolars in a Saudi Arab population: Dhahran, Saudi Arabia; 1993.

23. Yohanna W. Perawatan ortodontik pada geligi campuran. Bagian Ilmu Kedokteran Gigi Anak Fakultas Kedokteran Gigi Universitas Padjajaran. Bandung; 2010.

24. Green-Thompson NF. Measuring and predicting using computer imaging analysis. Johannesburg: University of the Witwatersrand; 2007.

25. Moyers RE. Handbook of orthodontics. $\quad 4^{\text {th }}$ ed. Yearbook Medical Pub Inc Chicago; 1988; 235-8.

26. Hixon EH, Oldfather RE. Estimation of the sizes of unerupted cuspid and bicuspid teeth [Iowa: State University of Iowa; 1958; 236-240. 
27. Irwin RD, Herold JS, Richardson A. Mixed dentition analysis: a review of methods and their accuracy. Int $\mathbf{J}$ Paediatr Dent; .1995; 5(3):137-4.

28. Green-Thompson NF. Measuring and predicting leeway space in mixed dentition on panoramic $\mathrm{x}$ rays using computer imaging analysis. University of the Witwatersrand. Johannesburg; 2007.

29. Levelle CLB, Foster TD, Flinn RM.Dental arches in various ethnic groups. J Angle Orthod; 1971; 41(4): 293-9.

30. Irsa R, Syaifullah, Tjong DH. Variasi Kefalometri pada Beberapa Suku di Sumatera Barat Cephalometry variation of ethnics in West Sumatra. Padang: Universitas Andalas; 2013; 130137.

31. Sutan AS. Perbandingan vaiditas analisis Tanaka-Johnston dan analisis Moyers pada mahasiswa suku Batak Universitas Sumatera Utara. [Medan: Universitas Sumatera Utara; 2013.p.1-24.

32. Megawaty. Prediksi Leeway space dengan menggunakan metode Tanaka-Johnston pada murid sekolah dasar ras deutro-melayu di kecamatan Medan Helvetia [Medan: Universitas Sumatera Utara; 2014.
33. Decland E Ward, Workman J, Brown R, Richmond S. Changes in arch width after treatment. Angle Orthod; 2006; 76(1): 6-13

34. Budiman JA, Yashadana EDD, Sadosa SD, Masbirin PI 1997.Hubungan rasio anterior dengan overjet dan overbite pada perawatan ortodontik. Jurnal Kedokteran Gigi Universitas Indonesia; 2006; 4(3): 19-25

35. Alvesalo, L. The influence of sexchromosome genes on tooth size in man. A genetic and quantitative study. Proc Finn Dent Soc; 1971; 67: 3-54.

36. Dewanto H. Aspek-Aspek Epidemiologi Maloklusi. Gajah Mada University Press; Yogyakarta; 1993.

37. Dempsey, P. J., Townsend. Genetic and environmental contributions to variation in human tooth size. Australia; 2000.

38. Sastroasmoro, Sudigdo. DasarDasar Metodologi Penelitian Klinis. CV. Sagung Seto; Jakarta; 2011.

39. Notoatmodjo, Soekidjo. Metodologi Penelitian Kesehatan.Rineka Cipta: Jakarta; 2010 . 